\title{
Gleditsia aquatica, Water Locust ${ }^{1}$
}

\section{Michael G. Andreu, Melissa H. Friedman, and Robert J. Northrop ${ }^{2}$}

\section{Family}

Fabaceae, legume or pea family

\section{Genus}

Gleditsia is the name of the locust genus. Linnaeus, who is also known as the father of taxonomy, gave the name to this genus in 1748 to honor his colleague, Johann Gottlieb Gleditsch, who directed the Berlin Botanical Gardens.

\section{Species}

The species name aquatica comes from the Latin word aqua, which means "water," and refers to the tree's preference for wet or boggy soils.

\section{Common Name}

\section{Water locust}

The name "water locust" is a direct translation of the scientific name of this tree, with Gleditsia referring to the locust genus and aquatica translating to water.

\section{Description}

This deciduous tree is native to Florida and its natural range stretches from South Carolina to central Florida, across Louisiana to eastern Texas, and up the Mississippi River valley to southern Illinois and Indiana. Water locust can grow well in both sunny and shady conditions as long as

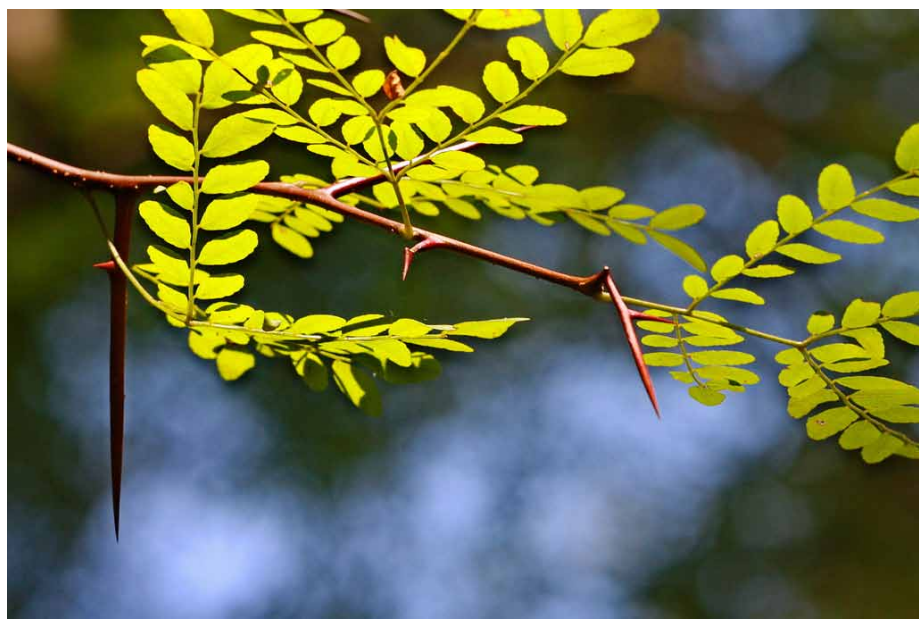

Figure 1. Water Locust (Gleditsia aquatica), Tosohatchee Wildlife Management Area, Orange County, FL, July 2012

Credits: Mary Keim, CC BY-NC-SA 2.0, http://flic.kr/p/cFNUaS

it receives plenty of water. It generally reaches 75 feet in height, but heights of up to 90 feet have also been reported. The leaves are bipinnately compound and are 12-30 inches long. Leaflets are oval in shape, 1-3 inches long, have a shiny surface and smooth edges, and occur in 6-14 pairs on a leaf. Three- to 5-inch-long thorns may protrude through the thin, grayish-brown bark of the trunk and branches. Male and female flowers are small, greenish white, and bell shaped. Flowers bloom in late spring and appear in clusters on soft, vertical, twig-like structures that only flowers grow on. Fruits are 1- to 2-inch-long flat pods that are dark brown and shiny. Pods mature late in the summer months, are dehiscent or open on their own when ripe, and contain one, flattened, round seed, rarely exhibiting up to three.

1. This document is FOR301, one of a series of the School of Forest Resources and Conservation, Florida Cooperative Extension Service, Institute of Food and Agricultural Sciences, University of Florida. Original publication date July 2012. Visit the EDIS website at http://edis.ifas.ufl.edu.

2. Michael G. Andreu, associate professor; Melissa H. Friedman, research scientist; School of Forest Resources and Conservation; and Robert J. Northrop, Extension forester, Hillsborough County Extension; University of Florida, Gainesville, Florida 32611. 


\section{Allergen}

Pollen from Gleditsia spp. is moderately allergenic.

\section{Applications}

\section{Commercial/Practical}

Water locust wood is hard and strong and has been used to make fence posts over the last century. Additionally, the wood is desirable for cabinetry, although this is less well known because lumber from this tree is generally scarce.

\section{Horticultural}

Water locust's wide, spreading root system and affinity for hydric conditions makes it a useful specimen for erosion control on wet banks of freshwater systems. While not widely available, planting this tree in residential yards or other public locations may be less than ideal, since the long and sharply pointed thorns on the main trunk and branches can be hazardous.

\section{Additional References}

Grimm, W. C. (2002). The Illustrated Book of Trees. Mechanicsburg, PA: Stackpole Books.

Seiler, J., Jenson, E., Niemiera, A., \& Peterson, J. (2011). Waterlocust Fabaceae Gelditsia aquatica Marsh. Virginia Tech. Retrieved from http://dendro.cnre.vt.edu/dendrology/syllabus/factsheet.cfm?ID=407.

USDA Plants Database (n.d.). Gleditsia aquatica Marsh. Water Locust. Retrieved from http://plants.usda.gov/java/pr ofile? symbol=GLAQ\&photoID=glaq_002_avd.tif. 